\title{
Reform of the NDRC or Mutations in Central Planning
}

Thibaud Voïta

\section{(2) OpenEdition \\ Journals}

Electronic version

URL: http://journals.openedition.org/chinaperspectives/3873

DOI: 10.4000/chinaperspectives.3873

ISSN: 1996-4617

Publisher

Centre d'étude français sur la Chine contemporaine

\section{Printed version}

Date of publication: 4 April 2008

Number of pages: 106-107

ISSN: 2070-3449

\section{Electronic reference}

Thibaud Voïta, « Reform of the NDRC or Mutations in Central Planning », China Perspectives [Online] 2008/2 | 2008, Online since 01 April 2011, connection on 15 September 2020. URL : http:// journals.openedition.org/chinaperspectives/3873 


\title{
Reform of the NDRC, or Mutations in Central Planning
}

\author{
Analysis by Thibaud Voïta
}

Based on:

- Luo Changpin et al., "A silhouette begins to appear," Caijing, 17 March 2008.

- Zuo Qinglin, "The return of the NDRC to its initial functions," 21 Shiji jingii baodao, 18 March 2008.

- Wang Dongming, "Another step in the reform of administrative management and government institutions," Qiu shi, 1 April 2008.

$\mathrm{T}$

he National Development and Reform Commission (NDRC) is nicknamed the "Ministry of Ministries" or "the first major Chinese ministry." According to Caijing, the NDRC has been at the centre of reform since its creation. It emerged in 1988 as the National Planning Commission following a merger with the National Economic Commission. Between 1993 and 1998, it played a macroeconomic regulatory role between the various ministries before becoming so powerful at the end of the 1990s that it was nicknamed the "Little State Council."

The NDRC under its present name was created in 2003 with wider powers. It found itself entrusted with dossiers as important as macroeconomic regulation, administrative reform, allocation of resources, and price regulation. Its functions include the selection of national holidays. At least 28 Ministries and State Council institutions have daily contacts with the NDRC.

The reforms affecting the Commission during the last session of the National People's Congress (NPC) call into question a considerable number of its attributes. Officially it is a matter of refocusing: the NDRC has been stripped of its microeconomic and project approval activities in order to concentrate on macroeconomic policies. "Our work is going to be more precise," is the euphemistic statement from NDRC cadres.

The career of the new head of the NDRC, Zhang Ping, gives some indication of the direction of reform. Born in northern Anhui in 1946, he experienced the realities of peasant poverty. He spent his entire career in his native province before coming to Beijing, and he has been deeply involved in solving rural problems. He is mainly remembered for his tax reforms; in his native province he is talked of as "the first person to concern himself with rural taxation."

He joined the NDRC in 2005 as deputy minister in charge of managing the economy, trade, and prices. As such, he headed the departments of trade, of price inspection, of the price examination centre, of publishing for the Chinese market, and of the centre for the assessment of the prices of medicines, as well as the National Cereal Board. He distinguished himself in this position by controlling the cost of education, reducing the price of medical treatment, controlling property prices, reforming energy prices, and stabilising agricultural prices. It appears that the departments he headed will now be at the heart of the NDRC, with most of the others having been detached from the Commission.

Caijing celebrates these reforms. The NDRC was overlarge, and the new distribution of powers should limit its authority over investment authorisations by reassigning them to local governments. The sharing of power between the centre and the regions should be clearer as a consequence, and local governments given more responsibility. The reallocation of certain responsibilities to major ministries is also considered a positive aspect. Caijing emphasises this new reallocation of responsibilities in the energy sector, which mainly concerns four institutions:

1) the Energy Leading Group, led by Wen Jiabao;

2) the Leading Group Committee, within the NDRC itself, which will deal with everyday business;

3) the Energy Committee of the NDRC; and

4) the Electricity Regulation Committee, created in 2003. Henceforth the Energy Committee will be one level above the NDRC in the hierarchy. Zhang Guobao, former Vice-Minister of the NDRC in charge of energy, is likely to become its leader.

What conclusions can be drawn from this reorganisation? Firstly, Wang Dongming emphasises the transition towards a service government seen as an essential step in constructing a "socialist society with Chinese characteristics" by 
2020. One will notice that Zhang Ping has been concerned with rural questions throughout his career. He was also responsible for the price management centres when price control measures were introduced several months ago. Central planning therefore seems to be moving towards improving management of public social services in order better to share the benefits of growth. Secondly, the reduction of the NDRC's prerogatives does not necessari- ly mean less interventionism in the economy on the part of the central government. On the contrary, this refocusing should allow the NDRC to devote itself more extensively to macroeconomic management. In the wake of the latest session of the NPC, the objective is thus rationalisation of State action. $\bullet$

\section{- Translated by Michael Black}

\section{The principal reforms in Chinese administration since the opening up of the country}

1982: Reduction of the size of government institutions: the number of institutions under the control of the State council is reduced from 100 to 61 .

1988: Further reduction in the number of institutions: 19.2 percent reduction in government personnel.

1993: Objective of building "market socialism," separation between government and enterprises. The number of institutions under direct government control is reduced by 20 percent, from 86 to 58 .

1998: Transition in government functions, launch of enterprise reforms. The number of institutions dependent on the State Council declines from 40 to 29, and some functions are transferred to enterprises, local governments, and the people. The number of state employees is halved. Creation of the Commission of Science, Technology, and Industry for National Defence (Costind), and the ministries of Information, Social Protection and Workers, and Land Ownership.

2003: The government's responsibilities are henceforth to regulate the economy, the market, society, and public affairs. Establishment of the State-Owned Assets Supervision and Administration Commission (SASAC), the NDRC, and the China Banking Regulatory Commission (CBRC). Reorganisation of the Ministry of Commerce and of the State Food and Drug Administration. The State Administration of Work Safety is placed under the direct control of the State Council. 